\title{
Effect of Bentonite Fining on Polyfunctional Mercaptans and Other Volatile Compounds in Sauvignon blanc Wines
}

\author{
Eduardo Vela, ${ }^{1}$ Purificación Hernández-Orte, ${ }^{1}$ Eva Castro, ${ }^{1}$ \\ Vicente Ferreira, ${ }^{1}$ and Ricardo Lopez ${ }^{1 *}$
}

\begin{abstract}
Bentonite fining is the most common process used in the wine industry to remove proteins from wine. Herein, the influence of fermentative and post-fermentative fining on aroma compounds found in Sauvignon blanc wines was studied. Sauvignon blanc musts from different vintages were fined using bentonite. Conventional enological parameters, together with more than 60 volatile compounds, including varietal thiols, were determined in the bottled wines. The results showed that bentonite fining was more effective in removing proteins from wine when carried out on finished wines. Several volatile compounds were influenced by bentonite fining depending on the timing of addition and the vintage. Varietal thiols, key compounds of Sauvignon blanc wine aroma, were significantly reduced when the wines were fined with bentonite, particularly when fining took place during fermentation. Results suggest that bentonite fining of musts could damage the organoleptic quality and varietal character of Sauvignon blanc wines because of its impact on polyfunctional mercaptans.
\end{abstract}

Key words: bentonite fining, polyfunctional mercaptans, wine volatile compounds

The appearance of lees or turbidity can often be observed in commercial white wines, primarily because of the presence of tartaric acid salts (potassium bitartrate and calcium tartrate) and insoluble proteins. Sediments formed by proteins are caused by their denaturation, aggregation, flocculation, and, finally, their precipitation (Waters et al. 2005). Proteins originate from grapes and yeast autolysis, the former being the main cause of sedimentation problems (Waters et al. 2005). Proteins play a fundamental role in the fermentation process and form part of the final composition of wine. The protein concentration depends on many factors, among the most important being the grape cultivar, the soil type, and winemaking techniques. Nevertheless, no direct correlation between protein concentration and potential sediment formation has been demonstrated because, even with small concentrations of proteins, sediment formation can be induced by changes in temperature or $\mathrm{pH}$ (Sarmento et al. 2000).

Protein sediments are amorphous, spongy, and slightly compacted. This causes turbidity and, consequently, the consumer's rejection of the affected wine (Waters et al. 2005). The problem can be avoided by using various protein-based fining agents (casein or gelatin) or non-proteic agents (bentonite or silica gel) (Ribéreau-Gayon 2000). Currently, the most widely used agent is bentonite because of its low cost, high efficiency, and ease of use. As reported by several authors

\footnotetext{
${ }^{1}$ Laboratory for Aroma Analysis and Enology, Instituto Agroalimentario de Aragón (IA2), Department of Analytical Chemistry, Faculty of Sciences, Universidad Zaragoza, E-50009 Zaragoza, Spain.

*Corresponding author: (riclopez@unizar.es; tel: +34876553330; fax $+34976761292)$

Manuscript submitted May 2016, revised Aug 2016, accepted Aug 2016

Copyright (C) 2017 by the American Society for Enology and Viticulture. All rights reserved.

doi: 10.5344/ajev.2016.16052
}

(Sanborn et al. 2010, Chagas et al. 2012), bentonite is one of the most effective products for protein haze removal from white wines. This fine-grained montmorillonite-type clay has a laminar structure that contains exchangeable cations. Sodium and calcium, the main ions present in bentonite, are the cations responsible for its swelling and ionic exchange attributes (Blade and Boulton 1988, Catarino et al. 2008). These physicochemical properties of bentonites produce a strong negative charge over a large adsorption surface. The mechanism of protein removal is the adsorptive interaction between positively charged proteins and negatively charged bentonites to produce a complex that will flocculate and settle as a flaky deposit (Ribéreau-Gayon 2000).

However, there are some disadvantages associated with the use of this clarifying agent, such as the amount of sediments produced which, because of their low level of compaction, can lead to substantial wine losses. Of no less importance are the changes in texture and flavor associated with the use of bentonites for protein stabilization (Waters et al. 2005). The decrease in flavor observed in wines treated with bentonite depends on the amount of bentonite employed for stabilization (Lambri et al. 2010) and depends on two processes: adsorption by the bentonite and indirect removal by the flocculating proteins, which can bind some aromatic compounds (Armada and Falque 2007). Previous studies have found that the aroma families primarily affected by treatments with bentonite are terpenes, C13-norisoprenoids, C6 alcohols, ethyl esters, and acetates (Moio et al. 2004, Armada and Falque 2007, Baiano et al. 2012).

Clarification with bentonite to obtain wines with protein stability can be performed at almost all stages of the winemaking process. Moreover, treatments with fining agents in white grape musts are required to improve fermentation and the quality of the wine obtained (Ayestaran et al. 1995). The use of bentonite in this step may favor sedimentation 
of suspended solids (Puig-Deu et al. 1999) while promoting must protein stabilization. Some authors have reported that the use of bentonite in must is more efficient and reduces loss of aromatic compounds (Lambri et al. 2012). However, other authors have reported that the best time to add bentonite is during fermentation, because a minimal amount is required and the concomitant removal of aromatic compounds is apparently lower (Miller et al. 1985, Pocock et al. 2011, Lira et al. 2015). Finally, other authors have reported that this type of treatment is more efficient in the finished wine (Somers and Ziemelis 1973, Puig-Deu et al. 1999). Because of the discrepancies in the results found in the literature, it is not possible to conclude what is the most appropriate time for the addition of bentonite during the winemaking process to minimize the impact on the wine aroma.

Sauvignon blanc is a native cultivar of the Bordeaux region in France. Its protein content is high, and the wines made from this variety tend to exhibit protein haze if not properly treated before bottling. This cultivar is highly valued for its distinctive aroma, described as green (vegetal, grassy, green pepper, herbaceous) and tropical (grapefruit and passion fruit) (Coetzee and du Toit 2012). The compounds causing some of these notes are polyfunctional mercaptans, specifically, 4-mercapto-4-methylpentan-2-one (4M4M2P), 3-mercaptohexan-1-ol $(3 \mathrm{MH})$, and 3-mercaptohexyl acetate (3MHA), which have a great impact on the wines of this cultivar (Mateo-Vivaracho et al. 2010). Many studies have been published in which the effect of bentonite on the profile of the volatile compounds has been discussed, but to the best of our knowledge, only one of these has assessed the influence of bentonite fining on varietal thiols (Parish et al. 2016). However, in the cited study, bentonite was used in low amounts and together with other fining agents, which makes it difficult to evaluate the real influence of bentonite on polyfunctional mercaptans.

The present study had two goals. The first was to establish the optimal timing for fining with bentonite, and the second was to assess the effect of bentonite on the aromatic composition of wine, and particularly on the polyfunctional mercaptans. To achieve these goals, a pilot plant scale fermentation was carried out using Sauvignon blanc grapes, to test different amounts of bentonite at different times, and exhaustively analyze the volatile chemical composition of the wines produced.

\section{Materials and Methods}

Winemaking. All treatments and fermentations were carried out in the Food Science and Technology pilot plant at the Veterinary Faculty of the University of Zaragoza, Spain. The musts of two vintages (2014 and 2015) were taken from a Sauvignon blanc cultivar provided by Viñas del Vero (Barbastro, Spain). The must was placed in 10-L tanks. Musts were mixed with $50 \mathrm{mg} / \mathrm{L}$ of total $\mathrm{SO}_{2}$ before alcoholic fermentation. Viniferm RVA yeasts (Agrovin, Spain) were used to inoculate the wine at $10 \mathrm{~g} / \mathrm{hL}$. Alcoholic fermentation took place at a constant temperature of $18^{\circ} \mathrm{C}$ and was monitored by measuring the density and temperature daily. After alcoholic fermentation, the wines were racked, adjusted to $30 \mathrm{mg} / \mathrm{L}$ of free $\mathrm{SO}_{2}$, and samples were taken for stability analysis and the determination of enological parameters and aromas. All fermentations were carried out in duplicate for the two vintages of the study.

The initial musts used in the two vintages had the following characteristics. Year 2014: density, $1088 \mathrm{~kg} / \mathrm{m}^{3}$; total acidity, $6.22 \mathrm{~g} / \mathrm{L}$, expressed as tartaric acid; $\mathrm{pH}$ 3.41; yeast assimilable nitrogen (YAN), $291 \mathrm{mg} / \mathrm{L}$; initial turbidity, 224 nephelometric turbidity units (NTU). Year 2015: density, 1105 $\mathrm{kg} / \mathrm{m}^{3}$; total acidity, $5.70 \mathrm{~g} / \mathrm{L}$, expressed as tartaric acid; $\mathrm{pH}$ 3.35; YAN, $300 \mathrm{mg} / \mathrm{L}$; initial turbidity, 300 NTU. All alcoholic fermentations had a similar rate, with fermentations of eight days for 2014, and nine days for 2015, with controlled temperatures of $18 \pm 2^{\circ} \mathrm{C}$.

Bentonite treatment. The bentonite used was Bentogran (AEB) in granular form. Bentonite treatments were performed at two different times: addition to the must once the fermentation had just begun, at 20 density units below the initial must value ("Must fining"), and addition to the finished wine just after the end of the alcoholic fermentation ("Wine fining"). The bentonite was added to the 2015 must in doses of 50 and $100 \mathrm{~g} / \mathrm{hL}$ and to the 2014 must in doses of 50, 75, and $100 \mathrm{~g} /$ $\mathrm{hL}$. At the end of the alcoholic fermentation, heat tests were performed and the samples treated with $100 \mathrm{~g} / \mathrm{hL}$ were selected for posterior analysis.

Heat tests were carried out on the finished wines obtained without treatment of the must to find the minimum concentration of bentonites needed to remove the unstable proteins. Those concentrations were 75 and $50 \mathrm{~g} / \mathrm{hL}$ for the 2014 and 2015 vintages, respectively. After five days of contact, the wines were racked, sulfited, and bottled, and samples for analysis were taken. Control wines, without bentonite addition, were also produced for each vintage.

Determination of protein instability by heat test. Fifty $\mathrm{mL}$ of wine samples were centrifuged at $4500 \mathrm{rpm}$ for 15 min (Allegra X-22R Beckman Coulter). The turbidity of the supernatant was measured by nephelometry (HI 93703 C D turbidimeter, Hanna). Samples were heated for $30 \mathrm{~min}$ at $80^{\circ} \mathrm{C}$ in a controlled water bath and left for $4 \mathrm{hr}$ at $25^{\circ} \mathrm{C}$, and the turbidity was measured again. The differences in turbidity measured before and after the heat treatment are proportional to protein instability. Wines can be considered stable if the difference does not exceed 2 NTU (Moine-Ledoux and Dubourdieu 1999, Sarmento et al. 2000).

Chemical analysis of musts and wines. Conventional enological parameters of musts and wines (density, YAN, total acidity, $\mathrm{pH}$, alcoholic content, reducing sugars, and volatile acidity) were measured in accordance with the protocols issued by the Office International de la Vigne et du Vin (OIV 2014).

Determination of organic acids. Tartaric, malic, and lactic acids were determined by high-performance liquid chromatography (HPLC). Sample treatment: $1 \mathrm{~mL}$ of wine and $1 \mathrm{~mL}$ of $1 \mathrm{M} \mathrm{H}_{3} \mathrm{PO}_{4}$ were loaded onto a pre-conditioned Sep-Pak C-18 cartridge. The organic acids were eluted with an aqueous solution of $5 \times 10^{-3} \mathrm{M}$ phosphoric acid to a final volume of $10 \mathrm{~mL}$. These samples were filtered through a 0.45 $\mu \mathrm{m}$ filter before injection. 
The HPLC used was a Waters Alliance 2695 separation module connected to a Varian Prostar 330 diode array detector. The separation was carried out in a $250 \mathrm{~mm} \times 10 \mathrm{~mm}$ i.d. column (Luna C18 bonded silica $4.6 \mu \mathrm{m}$ particle size) supplied by Analytical Phenomenex. Detection was carried out by recording the signal at $210 \mathrm{~nm}$. The injection volume was $20 \mu \mathrm{L}$. The eluent was aqueous $5 \times 10^{-3} \mathrm{M} \mathrm{H}_{3} \mathrm{PO}_{4}$ in isocratic mode at $0.6 \mathrm{~mL} / \mathrm{min}$. Quantification of the acids was carried out by interpolating the areas of samples on a calibration curve prepared from known concentration standards of each acid.

Determination of tartaric instability. Ten $\mathrm{mL}$ of wine was cooled for six days at $4^{\circ} \mathrm{C}$ in a water bath. Before and after cooling, the concentration of tartaric acid in the wine was determined following the protocol for organic acids mentioned above. Wines were considered stable when the differences in the concentrations of tartaric acid before and after cooling were equal to or less than $0.1 \mathrm{~g} / \mathrm{L}$.

Chemical quantitative analysis of volatile compounds. Major compounds (liquid-liquid microextraction and GCFID analysis). Quantitative analysis of the major compounds was carried out using the method proposed and validated by Ortega et al. (2001). In accordance with this method, $3 \mathrm{~mL}$ of wine and $7 \mathrm{~mL}$ of water were salted with $4.5 \mathrm{~g}$ of ammonium sulfate and extracted with $200 \mu \mathrm{L}$ of dichloromethane. The extract was then analyzed by gas chromatography (GC) with flame ionization detection (FID) using the conditions described elsewhere (Ortega et al. 2001). Quantitative data were calculated by interpolation of relative peak areas in the calibration graphs obtained by the analysis of synthetic wines containing known amounts of the analytes. 2-Butanol, 4-methyl-2-pentanol, 4-hydroxy-4-methyl-2-pentanone, and 2-octanol, at a concentration of $200 \mu \mathrm{g} / \mathrm{g}$ in dichloromethane, were used as internal standards. The extract was analyzed by GC with FID.

Minor compounds (SPE and GC-ion trap-MS analysis). This analysis was carried out using the method proposed and validated by Lopez et al. (2002) with the following changes in the previous procedure: standard solid phase extraction (SPE) cartridges (1 mL, total volume) filled with $200 \mathrm{mg}$ of LiChrolut EN resins were placed in the vacuum manifold extraction system (Varian Sample Preparation Products), and the sorbent was conditioned by rinsing the cartridges with 4 $\mathrm{mL}$ of dichloromethane, $4 \mathrm{~mL}$ of methanol, and, finally, with $4 \mathrm{~mL}$ of a water-ethanol mixture $(12 \%, \mathrm{v} / \mathrm{v})$. The cartridges were then loaded with $50 \mathrm{~mL}$ of wine sample and $26 \mu \mathrm{L}$ of a surrogate standards solution (recovery standard) containing 3 -octanone, $\beta$-damascone, and heptanoic acid (all at $200 \mu \mathrm{g} / \mathrm{g}$ of ethanol). This mixture was passed through the SPE cartridges $(2 \mathrm{~mL} / \mathrm{min})$, followed by a washing step using $5 \mathrm{~mL}$ of a $30 \%$ methanol in water and $1 \% \mathrm{NaHCO}_{3}$ solution. The resins were then dried by letting air pass through them (negative pressure of $0.6 \mathrm{bar}, 10 \mathrm{~min}$ ). Analytes were recovered in a $2-\mathrm{mL}$ vial by elution with $1.6 \mathrm{~mL}$ of dichloromethane. Thirty-four $\mu \mathrm{L}$ of an internal standard solution $(300 \mathrm{mg} / \mathrm{L}$ of 4-hydroxy-4-methyl-2-pentanone and 2-octanol) was added to the eluted sample. The extract was analyzed by GC with ion trap-mass spectrometry (MS) detection (GC-450 gas chromatograph fitted to a Varian Saturn 2200 ion trap-MS).

Polyfunctional mercaptans (SPE and GC-negative chemical ionization-MS analysis). The analysis of 2-furfurylthiol (FFT), 4-mercapto-4-methylpentan-2-one (4M4M2P), 3MHA, 3-mercaptohexan-1-ol (3MH), 2-methyl-3-furanthiol (MFT), and benzyl mercaptan (BM) in the samples was performed according to a previously validated method (Mateo-Vivaracho et al. 2010). The mercaptans were retained in a cartridge and directly derivatized on fiber by first being passed through a solution of DBU (6.7\%). The cartridge was rinsed with a solution of pentafluorobenzylbromide. The derivatized analytes were finally eluted with $600 \mu \mathrm{L}$ of a solvent mixture ( $25 \%$ hexane in diethyl ether). The eluate was washed five times with $1 \mathrm{~mL}$ of brine $(200 \mathrm{~g} / \mathrm{L} \mathrm{NaCl}$ water solution), transferred to a $2-\mathrm{mL}$ vial, and spiked with a small amount of anhydrous sodium sulfate. Four $\mu \mathrm{L}$ of this sample was directly injected in cold splitless mode into the GC-negative chemical ionization-MS system. The apparatus was a Shimadzu QP-2010Plus gas chromatograph with a quadrupole mass spectrometric detection system. MFT concentration was expressed as ng/L of FFT.

Statistical analysis. One-way analysis of variance (ANOVA) for each vintage was performed with the statistical software package SPSS 19.0 (SPSS Inc.).

\section{Results and Discussion}

Selection of the bentonite concentration. At the end of the alcoholic fermentation, the wines produced with the musts treated with different concentrations of bentonite were racked and left to decant for one week. Protein instability tests were carried out on these wines to determine the efficiency of the bentonite fining treatments. Table 1 shows that, as expected, the increase in the amount of bentonite added to the must in fermentation decreased the turbidity of the finished wines. However, in both vintages, a $100 \mathrm{~g} / \mathrm{hL}$ concentration of bentonite was required for protein stability $(\triangle \mathrm{NTU} \leq 2)$.

For the wines obtained without any must treatment, three different concentrations of bentonite were tested to determine the minimum concentration that stabilized the wine proteins. Table 1 shows that these concentrations were $75 \mathrm{~g} / \mathrm{hL}$ in the 2014 wines, and $50 \mathrm{~g} / \mathrm{hL}$ in the 2015 wines.

The data indicate that fining in must was less effective than in wine because higher concentrations of bentonite were required when the addition occurred at the beginning of the fermentation. These results do not agree with those obtained

Table 1 Protein instability test. Differences in turbidity $(\Delta N T U)$ obtained in the heat test with the different bentonite treatments of musts and wines.

\begin{tabular}{llcccc}
\hline & & \multicolumn{4}{c}{ Bentonite $(\mathbf{g} / \mathbf{h L})$} \\
\cline { 3 - 6 } Year & & $\mathbf{0}$ & $\mathbf{5 0}$ & $\mathbf{7 5}$ & $\mathbf{1 0 0}$ \\
\hline \multirow{2}{*}{2014} & Must fining & - & 26.6 & 6.1 & 2.0 \\
& Wine fining & 16.1 & 2.8 & 2.0 & 1.1 \\
2015 & Must fining & - & 3.6 & - & 1.6 \\
& Wine fining & 15.8 & 0.5 & 0.3 & 0.1 \\
\hline
\end{tabular}


with Sauvignon blanc, Semillon, or Riesling juices (Pocock et al. 2011), nor with the most recent data obtained with Albariño musts (Lira et al. 2013, 2014, 2015). However, in both studies cited, the addition of bentonite took place in two stages, which could contribute to an improved adsorption of proteins. Other authors found that a single addition to Muscat must was better than the same addition to finished wine (Lambri et al. 2012), whereas others have obtained precisely the opposite results, such as those from an older study using Muscat (Somers and Ziemelis 1973). Such contradictory evidence could be related to differences in must composition, the exact timing of the bentonite addition, and the procedures used to determine protein instability.

In the present study, the effect of bentonite addition on enological parameters and on the aromatic composition of wine was assessed only with stable wines with $100 \mathrm{~g} / \mathrm{hL}$ of bentonite added at the beginning of alcoholic fermentation and those with $75 \mathrm{~g} / \mathrm{hL}$ (2014 vintage) and $50 \mathrm{~g} / \mathrm{hL}$ (2015 vintage) of bentonite added after the end of fermentation.

Influence of bentonite treatment on the conventional enological parameters, tartaric acid instability, and organic acids. The results obtained from the determination of the enological parameters are shown in Table 2. Nine conventional parameters were determined to study whether treatment with bentonite at the beginning or after alcoholic fermentation produced statistically significant changes in any of them. A one-way ANOVA was performed, comparing the control wine without bentonite fining with wines treated during and after the alcoholic fermentation. Some variations in those parameters were statistically significant, although the differences were minimal and not important at the enological level. Similar results have been found by other authors (Lambri et al. 2012, Lira et al. 2014). Table 2 also includes data relating to tartaric acid instability. As expected, all the wines were unstable regarding this parameter because the variation of the concentration of tartaric acid before and after cooling was above 0.1 units in all instances, therefore, the bentonite was not effective for the removal of tartaric acid instability.

Influence of bentonite treatment on volatile compounds. The volatile compound data obtained from the analysis of the wines are shown in Table 3 and Figure 1, arranged by chemical families. The data were explored using one-way ANOVA for each vintage, and showed a larger number of significant differences between treatments in the volatile compounds of the 2014 wines than in those of 2015 wines. This difference in the effect of bentonites on different wine vintages has been reported before (Lambri et al. 2012), although part of the difference could be caused by the different amount of bentonite used.

Among carbonyl compounds, acetoin appeared in higher quantities in wines treated with bentonites during alcoholic fermentation (this trend also appeared in the 2015 wines). Other authors have not found these differences for acetoin when studying model wines treated with bentonite (Vincenzi et al. 2015). However, the differences were not relevant to the aroma because the measured quantities of acetoin were below its odor threshold. The other carbonyl compound that showed significant differences was benzaldehyde, which was found in lower quantities in the wines fined with bentonites both during and after alcoholic fermentation. Similar results have been found in model wines (Vincenzi et al. 2015). As for acetoin, it is unlikely that the decrease has any influence on the wine aroma.

The influence of bentonites on the content of ethyl esters and acetates has been studied by many authors with mixed results. Some authors report significant losses of these molecules in model systems, although not for every bentonite tested (Voilley et al. 1990, Lambri et al. 2013, Vincenzi et al. 2015). In more complex systems, a Gewürztraminer wine fined with $100 \mathrm{~g} / \mathrm{hL}$ of bentonite showed a decrease in ethyl decanoate and phenylethyl acetate as compared to the control, while a Chardonnay wine in the same experiment showed mostly no differences in composition (Sanborn et al. 2010).

The influence of the addition of bentonite to must is variable, with no significant differences found in one study (Armada and Falque 2007), clear decreases associated with bentonite in compounds like ethyl butyrate or hexanoate in another study (Lambri et al. 2010), or even higher quantities of some compounds in musts fined with bentonites, as found in other studies (Lira et al. 2014, Parish et al. 2016). In

\begin{tabular}{|c|c|c|c|c|c|c|}
\hline \multirow[b]{2}{*}{ Parameter } & \multicolumn{3}{|c|}{ Year 2014} & \multicolumn{3}{|c|}{ Year 2015} \\
\hline & Control & Must fining & Wine fining & Control & Must fining & Wine fining \\
\hline$\overline{\mathrm{pH}}$ & $3.50 \pm 0.01 a^{a}$ & $3.48 \pm 0.01 \mathrm{~b}$ & $3.52 \pm 0.01 \mathrm{a}$ & $3.45 \pm 0.01$ & $3.48 \pm 0.01$ & $3.46 \pm 0.01$ \\
\hline Total acidity $(\mathrm{g} / \mathrm{L})^{\mathrm{b}}$ & $4.99 \pm 0.69$ & $4.58 \pm 0.11$ & $5.18 \pm 0.21$ & $3.81 \pm 0.03$ & $3.73 \pm 0.04$ & $3.79 \pm 0.05$ \\
\hline Alcohol (\% vol) & $12.6 \pm 0.3$ & $12.7 \pm 0.3$ & $13.0 \pm 0.4$ & $15.0 \pm 0.1$ & $14.9 \pm 0.1$ & $14.9 \pm 0.1$ \\
\hline Reducing sugars (g/L) & $0.2 \pm 0.1$ & $0.4 \pm 0.1$ & $0.2 \pm 0.1$ & $1.2 \pm 0.1$ & $1.6 \pm 0.9$ & $1.2 \pm 0.1$ \\
\hline Volatile acidity $(\mathrm{g} / \mathrm{L})^{\mathrm{c}}$ & $0.6 \pm 0.3$ & $0.3 \pm 0.1$ & $0.4 \pm 0.1$ & $0.4 \pm 0.1$ & $0.4 \pm 0.1$ & $0.4 \pm 0.1$ \\
\hline Tartrate instability ${ }^{d}$ & $1.71 \pm 0.03 a$ & $1.27 \pm 0.08 b$ & $1.73 \pm 0.02 \mathrm{a}$ & $1.59 \pm 0.08$ & $1.29 \pm 0.06$ & $1.55 \pm 0.16$ \\
\hline Tartaric acid & $2.95 \pm 0.09$ & $2.85 \pm 0.05$ & $2.90 \pm 0.06$ & $3.39 \pm 0.06 a$ & $2.84 \pm 0.04 b$ & $3.08 \pm 0.11 b$ \\
\hline Malic acid & $1.69 \pm 0.14$ & $1.56 \pm 0.06$ & $1.61 \pm 0.05$ & $1.46 \pm 0.02 b$ & $1.55 \pm 0.01 \mathrm{a}$ & $1.45 \pm 0.01 \mathrm{~b}$ \\
\hline Lactic acid & $0.40 \pm 0.19$ & $0.42 \pm 0.10$ & $0.28 \pm 0.01$ & $0.29 \pm 0.01$ & $0.25 \pm 0.04$ & $0.29 \pm 0.03$ \\
\hline
\end{tabular}

a a, b, c: Different letters indicate mean is significantly different among samples at $p<0.05$ by Duncan's test after a significant one-way ANOVA.

${ }^{\mathrm{b}}$ As tartaric acid.

${ }^{\mathrm{c}}$ As acetic acid.

${ }^{d}$ Variation of concentration of tartaric acid in $\mathrm{g} / \mathrm{L}$. 
the present study, only butyl acetate, ethyl hydrocinnamate, and ethyl cinnamate showed significant differences linked to bentonite treatment, but none of them reached their flavor threshold in wine. Other ethyl esters and acetates showed neither significant differences nor a clear trend of any impact of bentonite fining. These results agree with those reported previously, suggesting that the vintage and bentonite type are a larger source of variability than any individual bentonite fining technique (Lambri et al. 2012, 2013).
Among alcohols, only 1-butanol showed significant differences in the year 2014, with a lower content in wines treated with bentonites at the beginning of the alcoholic fermentation. These data are in accordance with previous findings in Albariño wines (Lira et al. 2015), but no real impact on wine aroma would be expected from the treatment.

The content of long-chain fatty acids in the final wines was affected by bentonite treatment, although in different directions in each vintage. The content of hexanoic, octanoic, and

Table 3 Impact of bentonite treatments on the concentration of aroma compounds detected in bottled wines $(\mathrm{n}=2)$.

\begin{tabular}{|c|c|c|c|c|c|c|c|}
\hline \multirow[b]{2}{*}{ Compounds } & \multirow[b]{2}{*}{ Threshold } & \multicolumn{3}{|c|}{ Year 2014} & \multicolumn{3}{|c|}{ Year 2015} \\
\hline & & Control & Must fining & Wine fining & Control & Must fining & Wine fining \\
\hline \multicolumn{8}{|l|}{ Carbonyl compounds } \\
\hline Acetaldehyde (mg/L) & $0.5^{\mathrm{a}}$ & nd & nd & nd & $0.58 \pm 0.32$ & $0.96 \pm 0.28$ & $0.81 \pm 0.06$ \\
\hline 2,3-butanodione (mg/L) & $0.1^{\mathrm{a}}$ & nd & nd & nd & nd & nd & nd \\
\hline Acetoin $^{\star 2014}(\mathrm{mg} / \mathrm{L})$ & $150^{\mathrm{b}}$ & nd $b$ & $1.21 \pm 0.10 \mathrm{a}$ & nd $b$ & $0.61 \pm 0.08$ & $0.81 \pm 0.40$ & $0.73 \pm 0.11$ \\
\hline Benzaldehyde*2014 ( $\mu \mathrm{g} / \mathrm{L})$ & $2000^{\mathrm{b}}$ & $6.39 \pm 0.62 a$ & $3.63 \pm 0.40 b$ & $4.16 \pm 0.11 b$ & $6.10 \pm 0.64$ & $5.91 \pm 1.18$ & $5.77 \pm 0.20$ \\
\hline \multicolumn{8}{|l|}{ Acetates } \\
\hline Ethyl acetate (mg/L) & $7.5^{\mathrm{a}}$ & $61.9 \pm 0.7$ & $53.9 \pm 5.0$ & $55.7 \pm 3.6$ & $46.8 \pm 20.3$ & $47.3 \pm 3.1$ & $53.6 \pm 8.9$ \\
\hline Isoamyl acetate (mg/L) & $0.03^{a}$ & $3.29 \pm 0.33$ & $3.60 \pm 0.35$ & $3.11 \pm 0.34$ & $5.80 \pm 0.12$ & $5.53 \pm 0.25$ & $6.52 \pm 0.88$ \\
\hline Hexyl acetate (mg/L) & $1.5^{\mathrm{b}}$ & $0.30 \pm 0.11$ & $0.33 \pm 0.03$ & $0.30 \pm 0.04$ & $0.58 \pm 0.06$ & $0.83 \pm 0.04$ & $0.67 \pm 0.16$ \\
\hline Isobutyl acetate $(\mu \mathrm{g} / \mathrm{L})$ & $1600^{c}$ & $53.5 \pm 0.1$ & $59.0 \pm 4.8$ & $62.3 \pm 1.6$ & $85.7 \pm 5.0$ & $79.6 \pm 6.2$ & $90.9 \pm 0.6$ \\
\hline Butyl acetate ${ }^{\star 2014}(\mu \mathrm{g} / \mathrm{L})$ & $1800^{\mathrm{b}}$ & $14.2 \pm 1.6 \mathrm{ab}$ & $12.6 \pm 0.3 b$ & $17.1 \pm 0.3 \mathrm{a}$ & $12.3 \pm 0.2$ & $12.3 \pm 1.4$ & $13.2 \pm 0.8$ \\
\hline Phenylethyl acetate ( $\mu \mathrm{g} / \mathrm{L})$ & $250^{a}$ & $228 \pm 12$ & $222 \pm 7$ & $230 \pm 9$ & $315 \pm 4$ & $313 \pm 33$ & $306 \pm 4$ \\
\hline \multicolumn{8}{|l|}{ Linear ethyl esters } \\
\hline Ethyl butyrate (mg/L) & $0.020^{a}$ & $0.58 \pm 0.07$ & $0.57 \pm 0.08$ & $0.50 \pm 0.05$ & $0.45 \pm 0.09$ & $0.44 \pm 0.01$ & $0.52 \pm 0.05$ \\
\hline Ethyl hexanoate (mg/L) & $0.014^{d}$ & $0.45 \pm 0.11$ & $0.54 \pm 0.04$ & $0.55 \pm 0.03$ & $0.73 \pm 0.09$ & $1.01 \pm 0.06$ & $0.86 \pm 0.21$ \\
\hline Ethyl octanoate (mg/L) & $0.58^{d}$ & $0.38 \pm 0.09$ & $0.49 \pm 0.08$ & $0.53 \pm 0.05$ & $0.51 \pm 0.05$ & $1.17 \pm 0.22$ & $0.75 \pm 0.47$ \\
\hline Ethyl decanoate (mg/L) & $0.2^{d}$ & nd & nd & nd & $0.07 \pm 0.02$ & $0.18 \pm 0.07$ & $0.09 \pm 0.07$ \\
\hline \multicolumn{8}{|l|}{ Branched ethyl esters } \\
\hline Ethyl isobutyrate $(\mu \mathrm{g} / \mathrm{L})$ & $15^{\mathrm{a}}$ & nd & nd & nd & $10.3 \pm 0.2$ & $12.7 \pm 0.1$ & $12.2 \pm 3.4$ \\
\hline Ethyl 2-methylbutyrate ( $\mu \mathrm{g} / \mathrm{L})$ & $18^{d}$ & $0.69 \pm 0.01$ & $0.92 \pm 0.04$ & $1.00 \pm 0.22$ & $0.66 \pm 0.25$ & $0.26 \pm 0.11$ & $0.37 \pm 0.17$ \\
\hline Ethyl isovalerate $(\mu \mathrm{g} / \mathrm{L})$ & $3^{a}$ & $6.58 \pm 0.54$ & $5.74 \pm 0.09$ & $6.25 \pm 0.66$ & $4.25 \pm 1.85$ & $4.32 \pm 0.67$ & $5.49 \pm 1.62$ \\
\hline \multicolumn{8}{|l|}{ Cinnamate esters } \\
\hline Ethyl dihydrocinnamate ( $\mu \mathrm{g} / \mathrm{L})$ & $1.6^{d}$ & nd & $0.21 \pm 0.01$ & nd & $0.15 \pm 0.01$ & $0.15 \pm 0.02$ & $0.15 \pm 0.01$ \\
\hline Ethyl cinnamate*2014 $(\mu \mathrm{g} / \mathrm{L})$ & $1.1^{d}$ & $0.35 \pm 0.04 a$ & $0.15 \pm 0.00 b$ & $0.36 \pm 0.02 \mathrm{a}$ & nd & nd & nd \\
\hline \multicolumn{8}{|l|}{ Other esters } \\
\hline Ethyl lactate (mg/L) & $150^{b}$ & $1.03 \pm 0.03$ & $1.02 \pm 0.02$ & $1.00 \pm 0.03$ & $1.54 \pm 0.16$ & $1.46 \pm 0.32$ & $1.76 \pm 0.01$ \\
\hline \multicolumn{8}{|l|}{ Alcohols } \\
\hline Isobutanol (mg/L) & $40^{\mathrm{a}}$ & $29.4 \pm 1.1$ & $31.5 \pm 1.1$ & $28.4 \pm 0.1$ & $21.9 \pm 5.2$ & $22.2 \pm 3.1$ & $27.4 \pm 3.6$ \\
\hline 1-butanol*2014 (mg/L) & $150^{\mathrm{b}}$ & $0.77 \pm 0.03 a$ & $0.66 \pm 0.03 b$ & $0.77 \pm 0.01 \mathrm{a}$ & $1.34 \pm 0.21$ & $1.21 \pm 0.27$ & $1.59 \pm 0.21$ \\
\hline Isoamyl alcohol (mg/L) & $30^{\mathrm{a}}$ & $168 \pm 14$ & $184 \pm 4$ & $175 \pm 20$ & $132 \pm 32$ & $136 \pm 16$ & $150 \pm 5$ \\
\hline 1-Hexanol (mg/L) & $8^{a}$ & $1.99 \pm 0.03$ & $2.02 \pm 0.02$ & $2.02 \pm 0.04$ & $1.26 \pm 0.10$ & $1.42 \pm 0.02$ & $1.25 \pm 0.13$ \\
\hline (Z)-3-hexenol (mg/L) & $0.4^{\mathrm{a}}$ & $0.11 \pm 0.01$ & $0.11 \pm 0.01$ & $0.11 \pm 0.01$ & $0.20 \pm 0.02$ & $0.21 \pm 0.01$ & $0.21 \pm 0.02$ \\
\hline Methionol (mg/L) & $1^{d}$ & $0.63 \pm 0.01$ & $0.67 \pm 0.02$ & $0.65 \pm 0.04$ & $0.68 \pm 0.02$ & $0.80 \pm 0.24$ & $0.76 \pm 0.04$ \\
\hline Benzyl alcohol (mg/L) & $200^{e}$ & $0.18 \pm 0.02$ & $0.17 \pm 0.01$ & $0.22 \pm 0.07$ & $0.23 \pm 0.01$ & $0.21 \pm 0.05$ & $0.24 \pm 0.02$ \\
\hline$\beta$-phenylethanol (mg/L) & $14^{d}$ & $14.5 \pm 1.1$ & $15.4 \pm 0.5$ & $16.0 \pm 3.0$ & $13.8 \pm 0.1$ & $14.2 \pm 2.1$ & $13.1 \pm 1.0$ \\
\hline \multicolumn{8}{|l|}{ Acids } \\
\hline Acetic acid (mg/L) & $300^{a}$ & $299 \pm 3$ & $240 \pm 12$ & $290 \pm 26$ & $423 \pm 3$ & $464 \pm 63$ & $421 \pm 8$ \\
\hline Butyric acid (mg/L) & $0.173^{d}$ & $1.42 \pm 0.08$ & $1.47 \pm 0.04$ & $1.29 \pm 0.13$ & $0.98 \pm 0.05$ & $0.98 \pm 0.01$ & $1.25 \pm 0.31$ \\
\hline Isobutyric acid (mg/L) & $2.3^{d}$ & $0.58 \pm 0.01$ & $0.49 \pm 0.02$ & $0.51 \pm 0.03$ & $0.95 \pm 0.11$ & $0.97 \pm 0.12$ & $1.24 \pm 0.35$ \\
\hline Isovaleric acid (mg/L) & $0.033^{d}$ & $0.65 \pm 0.07$ & $0.72 \pm 0.01$ & $0.63 \pm 0.07$ & $0.77 \pm 0.04$ & $0.76 \pm 0.07$ & $0.84 \pm 0.07$ \\
\hline Hexanoic acid²015 (mg/L) & $0.42^{d}$ & $4.62 \pm 0.23$ & $4.11 \pm 0.05$ & $4.93 \pm 0.80$ & $3.84 \pm 0.03 a b$ & $4.34 \pm 0.11 a$ & $3.62 \pm 0.26 b$ \\
\hline Octanoic acid ${ }^{\star 2014-2015}(\mathrm{mg} / \mathrm{L})$ & $0.5^{\mathrm{d}}$ & $7.89 \pm 0.13 a$ & $5.86 \pm 0.17 b$ & $7.84 \pm 0.62 \mathrm{a}$ & $7.40 \pm 0.23 b$ & $9.35 \pm 0.22 a$ & $7.51 \pm 0.74 b$ \\
\hline Decanoic acid²015 (mg/L) & $1^{d}$ & $0.52 \pm 0.14$ & $0.49 \pm 0.20$ & $0.71 \pm 0.15$ & $1.15 \pm 0.59 b$ & $2.80 \pm 0.33 a$ & $0.98 \pm 0.19 b$ \\
\hline
\end{tabular}


decanoic acids in the 2014 wine was lower when the bentonite was added at the beginning of the fermentation (not statistically significant for hexanoic and decanoic acids). Several authors found that musts fined with bentonite produce wines with lower quantities of fatty acids than those found in untreated wines (Armada and Falque 2007, Lambri et al. 2010). However, the 2015 wines showed the opposite trend, with higher content of these three long-chain fatty acids found in the wines obtained with musts fined with bentonite. These differences between vintages can be attributed to an impact of bentonite on the nutrients in the must rather than to a direct adsorption of fatty acids to the bentonite, because the addition took place at the beginning of the fermentation when their initial concentration was lower (Fraile et al. 2000). Regarding wine flavor, it is possible that these changes could have an influence on the perceived aroma because the fatty acids were above their aroma threshold in all wines.

In general, higher concentrations of terpinols were found in the control wines and in those fined after the end of the fermentation, while lower concentrations were found in wines made with musts treated with bentonite. The impact of bentonite treatment on musts has been reported before by other authors (Armada and Falque 2007, Lira et al. 2015). As found by Moio, this effect is caused by a loss of glycosidicallybound precursors rather than a direct adsorption of the free terpinols (Moio et al. 2004). These losses are likely to be irrelevant to the aroma of the Sauvignon blanc wines under study because the levels of these compounds were already low in all wines examined. In addition, the concentration of the norisoprenoid $\beta$-ionone was lower in the wines produced with must fining. Previous studies reported a connection between this compound and bentonites (Voilley et al. 1990, Lubbers et al. 1996). However, in the present study, this was not observed when bentonite was added to the finished wine, suggesting an interaction with $\beta$-ionone precursors.

The content of several phenols was influenced by bentonite fining. Specifically, eugenol, 4-vinylguaiacol, and 4-vinylphenol were found in lower concentrations in the wines produced with must fining. These variations could significantly impact the aroma of the wines, because both vinylphenols

Table 3 (continued) Impact of bentonite treatments on the concentration of aroma compounds detected in bottled wines $(n=2)$.

\begin{tabular}{|c|c|c|c|c|c|c|c|}
\hline \multirow[b]{2}{*}{ Compounds } & \multirow[b]{2}{*}{ Threshold } & \multicolumn{3}{|c|}{ Year 2014} & \multicolumn{3}{|c|}{ Year 2015} \\
\hline & & Control & Must fining & Wine fining & Control & Must fining & Wine fining \\
\hline \multicolumn{8}{|l|}{ Monoterpenes } \\
\hline Linalool $^{\star 2014}(\mu \mathrm{g} / \mathrm{L})$ & $25^{d}$ & $3.21 \pm 0.04 a$ & $2.62 \pm 0.10 b$ & $3.39 \pm 0.06 \mathrm{a}$ & $5.42 \pm 1.06$ & $4.69 \pm 0.22$ & $5.37 \pm 0.93$ \\
\hline Linalyl acetate ${ }^{\star 2014}(\mu \mathrm{g} / \mathrm{L})$ & & $1.64 \pm 0.15 a$ & $0.86 \pm 0.27 b$ & $1.76 \pm 0.03 \mathrm{a}$ & $0.59 \pm 0.47$ & $0.25 \pm 0.01$ & $0.55 \pm 0.35$ \\
\hline$\alpha$-Terpineol $(\mu \mathrm{g} / \mathrm{L})$ & $250^{d}$ & $0.87 \pm 0.08$ & $0.91 \pm 0.08$ & $0.79 \pm 0.05$ & $1.45 \pm 0.15$ & $1.31 \pm 0.08$ & $1.41 \pm 0.11$ \\
\hline$\beta$-Citronellol $(\mu \mathrm{g} / \mathrm{L})$ & $100^{\mathrm{b}}$ & $6.72 \pm 0.51$ & $5.87 \pm 0.46$ & $6.40 \pm 0.44$ & $3.35 \pm 0.06$ & $3.89 \pm 0.29$ & $3.28 \pm 0.21$ \\
\hline Geraniol ( $\mu \mathrm{g} / \mathrm{L})$ & $30^{a}$ & nd & nd & nd & $8.25 \pm 0.23$ & $8.81 \pm 0.73$ & $8.41 \pm 1.19$ \\
\hline \multicolumn{8}{|l|}{ Norisoprenoids } \\
\hline$\beta$-Damascenone $(\mu \mathrm{g} / \mathrm{L})$ & $0.05^{a}$ & $3.55 \pm 0.81$ & $3.66 \pm 0.78$ & $2.95 \pm 0.25$ & $3.90 \pm 0.52$ & $5.58 \pm 0.73$ & $4.82 \pm 0.26$ \\
\hline$\alpha$-Ionone $(\mu \mathrm{g} / \mathrm{L})$ & $2.6^{\mathrm{b}}$ & nd & nd & nd & $0.29 \pm 0.04$ & $0.30 \pm 0.06$ & $0.32 \pm 0.02$ \\
\hline$\beta$-Ionone ${ }^{\star 2014}(\mu \mathrm{g} / \mathrm{L})$ & $0.09^{d}$ & $0.45 \pm 0.05 a$ & $0.37 \pm 0.03 b$ & $0.47 \pm 0.01 \mathrm{a}$ & $0.15 \pm 0.01$ & $0.13 \pm 0.01$ & $0.15 \pm 0.01$ \\
\hline \multicolumn{8}{|l|}{ Phenols } \\
\hline Guaiacol ( $\mu \mathrm{g} / \mathrm{L})$ & $9.5^{\mathrm{a}}$ & $9.98 \pm 2.02$ & $11.4 \pm 6.7$ & $6.13 \pm 1.18$ & $4.22 \pm 0.67$ & $3.07 \pm 0.27$ & $4.06 \pm 0.63$ \\
\hline o-Cresol ( $\mu \mathrm{g} / \mathrm{L})$ & $31^{b}$ & $0.55 \pm 0.03$ & $0.45 \pm 0.07$ & $0.54 \pm 0.02$ & $0.28 \pm 0.04$ & $0.30 \pm 0.03$ & $0.26 \pm 0.04$ \\
\hline Eugenol ${ }^{2014-2015}(\mu \mathrm{g} / \mathrm{L})$ & $6^{d}$ & $0.92 \pm 0.07 a$ & $\mathrm{nd} b$ & $0.85 \pm 0.03 a$ & $0.78 \pm 0.04 a$ & $0.57 \pm 0.01 \mathrm{~b}$ & $0.71 \pm 0.05 a$ \\
\hline 4-Ethylphenol ( $\mu \mathrm{g} / \mathrm{L})$ & $35^{\dagger}$ & $0.15 \pm 0.05$ & $0.21 \pm 0.02$ & $0.15 \pm 0.03$ & $0.17 \pm 0.10$ & nd & $0.09 \pm 0.03$ \\
\hline 4-Vinylguaiacol*2014 $(\mu \mathrm{g} / \mathrm{L})$ & $40^{d}$ & $178 \pm 3 a$ & $148 \pm 1 b$ & $177 \pm 4 a$ & $214 \pm 10$ & $191 \pm 20$ & $211 \pm 10$ \\
\hline 2,6-Dimethoxyphenol ( $\mu \mathrm{g} / \mathrm{L})$ & $570^{\mathrm{g}}$ & $17.3 \pm 0.74$ & $15.5 \pm 11.4$ & $8.64 \pm 1.78$ & $4.81 \pm 1.07$ & $4.50 \pm 0.80$ & $4.66 \pm 0.77$ \\
\hline 4-Vinylphenol ${ }^{* 2014}(\mu \mathrm{g} / \mathrm{L})$ & $180^{\dagger}$ & $1351 \pm 163 a$ & $975 \pm 78.7 b$ & $1381 \pm 86.9 \mathrm{a}$ & $175 \pm 11.4$ & $148 \pm 14.2$ & $171 \pm 11.4$ \\
\hline 4-Alyll-2,6-dimethoxyphenol ( $\mu \mathrm{g} / \mathrm{L})$ & $1200^{h}$ & $0.82 \pm 0.07$ & $0.71 \pm 0.20$ & $0.63 \pm 0.11$ & $0.94 \pm 0.16$ & $0.64 \pm 0.01$ & $0.74 \pm 0.08$ \\
\hline \multicolumn{8}{|l|}{ Lactones } \\
\hline (Z)-Whiskey lactone $(\mu \mathrm{g} / \mathrm{L})$ & $67^{b}$ & nd & $5.92 \pm 0.17$ & nd & nd & nd & nd \\
\hline$\gamma$-Nonalactone $(\mu \mathrm{g} / \mathrm{L})$ & $30^{i}$ & $8.85 \pm 0.66$ & $8.67 \pm 0.43$ & $8.84 \pm 0.03$ & $2.93 \pm 0.33$ & $3.19 \pm 0.14$ & $2.70 \pm 0.30$ \\
\hline$\gamma$-Decalactone ${ }^{\star 2014}(\mu \mathrm{g} / \mathrm{L})$ & $0.7^{\mathrm{h}}$ & $1.19 \pm 0.09 b$ & $1.78 \pm 0.28 \mathrm{a}$ & $1.32 \pm 0.09 \mathrm{ab}$ & $6.46 \pm 0.31$ & $4.94 \pm 0.89$ & $5.66 \pm 0.86$ \\
\hline$\gamma$-Butyrolactone $(\mu \mathrm{g} / \mathrm{L})$ & $35000^{e}$ & $1240 \pm 70$ & $1150 \pm 90$ & $1260 \pm 40$ & $2380 \pm 30$ & $2470 \pm 120$ & $2670 \pm 90$ \\
\hline \multicolumn{8}{|l|}{ Vanilline derivatives } \\
\hline Vanillin $(\mu \mathrm{g} / \mathrm{L})$ & $995^{\mathrm{e}}$ & $3.87 \pm 0.58$ & $5.14 \pm 1.56$ & $3.46 \pm 0.71$ & $1.99 \pm 0.21$ & $1.91 \pm 0.06$ & $2.09 \pm 0.48$ \\
\hline Methyl vanillate $(\mu \mathrm{g} / \mathrm{L})$ & $990^{9}$ & $12.0 \pm 1.22$ & $11.6 \pm 0.28$ & $12.1 \pm 0.06$ & $4.62 \pm 0.24$ & $4.36 \pm 0.09$ & $4.54 \pm 0.20$ \\
\hline Ethyl vanillate ${ }^{\star 2015}(\mu \mathrm{g} / \mathrm{L})$ & $3000^{9}$ & $5.84 \pm 1.07$ & $4.04 \pm 0.10$ & $4.93 \pm 0.10$ & $1.81 \pm 0.36 \mathrm{a}$ & $0.84 \pm 0.01 b$ & $1.38 \pm 0.22 a b$ \\
\hline Acetovanillone $(\mu \mathrm{g} / \mathrm{L})$ & $1000^{j}$ & $20.5 \pm 1.73$ & $20.6 \pm 0.24$ & $21.1 \pm 0.48$ & $22.8 \pm 0.71$ & $21.2 \pm 0.19$ & $22.1 \pm 1.25$ \\
\hline
\end{tabular}

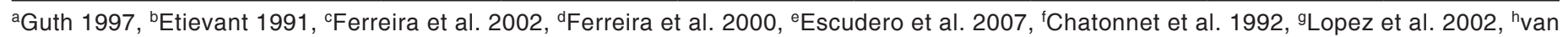
Gemert and Netenbreijer 1977, 'Nakamura et al. 1988, 'Escudero et al. 2004.

*Significant differences, ANOVA $(p \leq 0.05)$; nd: not detected.

$\mathrm{a}, \mathrm{b}, \mathrm{c}$ : Different letters indicate mean is significantly different among samples at $p<0.05$ by Duncan's test after a significant one-way ANOVA. 
were above their threshold concentrations, and the variation ranged from an $11 \%$ to a $28 \%$ loss. This could be explained by co-precipitation of the precursors (ferulic and $p$-coumaric acids) of these volatile phenols with specific proteins during the fining process (Stankovic et al. 2012). Other volatile compounds such as $\gamma$-decalactone and ethyl vanillate showed significant differences in the ANOVA study, but it is unlikely that these variations in composition could be detected in the wine aroma.

Polyfunctional mercaptans are key components of the aroma of Sauvignon blanc wines (Mateo-Vivaracho et al. 2010) that should be considered when evaluating the impact of bentonite fining. To our knowledge, only one recent publication addressed the influence of bentonite on $3 \mathrm{MH}$ and $3 \mathrm{MHA}$ (Parish et al. 2016). In the present study, six polyfunctional mercaptans were determined in the wines of the two different vintages (Figure 1). The content of varietal thiol 3MH in the finished wines was affected by bentonite treatment, with lower concentrations found in fined wines, more marked for the year 2014, and when the treatment was applied to musts. All the wines contained $3 \mathrm{MH}$ above its sensory threshold of $60 \mathrm{ng} / \mathrm{L}$, but the variation produced by the bentonite fining may modify the perception of the wine aroma. These results are not consistent with the previously mentioned work (Parish et al. 2016), where no significant differences were found in the content of $3 \mathrm{MH}$ in Sauvignon blanc musts fined with bentonite. The differences between both studies could be due to the addition of other fining agents simultaneously with bentonite or to a smaller concentration of bentonite in the experiment of Parish et al. (2016).

As expected, 3MHA content profile showed many similarities with that of $3 \mathrm{MH}$. In the 2014 vintage, 3MHA was found in the control wines and in those fined after fermentation at $\sim 30 \mathrm{ng} / \mathrm{L}$, which is above the aroma threshold of $4.2 \mathrm{ng} / \mathrm{L}$ (Tominaga et al. 1996). However, the wines elaborated with fined musts had noticeably lower levels of 3MHA (below 4 $\mathrm{ng} / \mathrm{L}$ ). The wines from the 2015 vintage showed a similar trend, although in that year, the decrease also occurred in the fined wines. This type of variability is expected to be present even within the same experiment. For example, in a previous study of New Zealand Sauvignon blanc wines, the bentonitetreated musts showed a significant decrease in 3MHA content in only one of four wines (Parish et al. 2016).

In a similar trend to that of $3 \mathrm{MH}$, the $4 \mathrm{M} 4 \mathrm{MP}$ content was reduced in must-fined wine to the point that it was below the detection limit of the method $(0.6 \mathrm{ng} / \mathrm{L})$. Other thiols detected
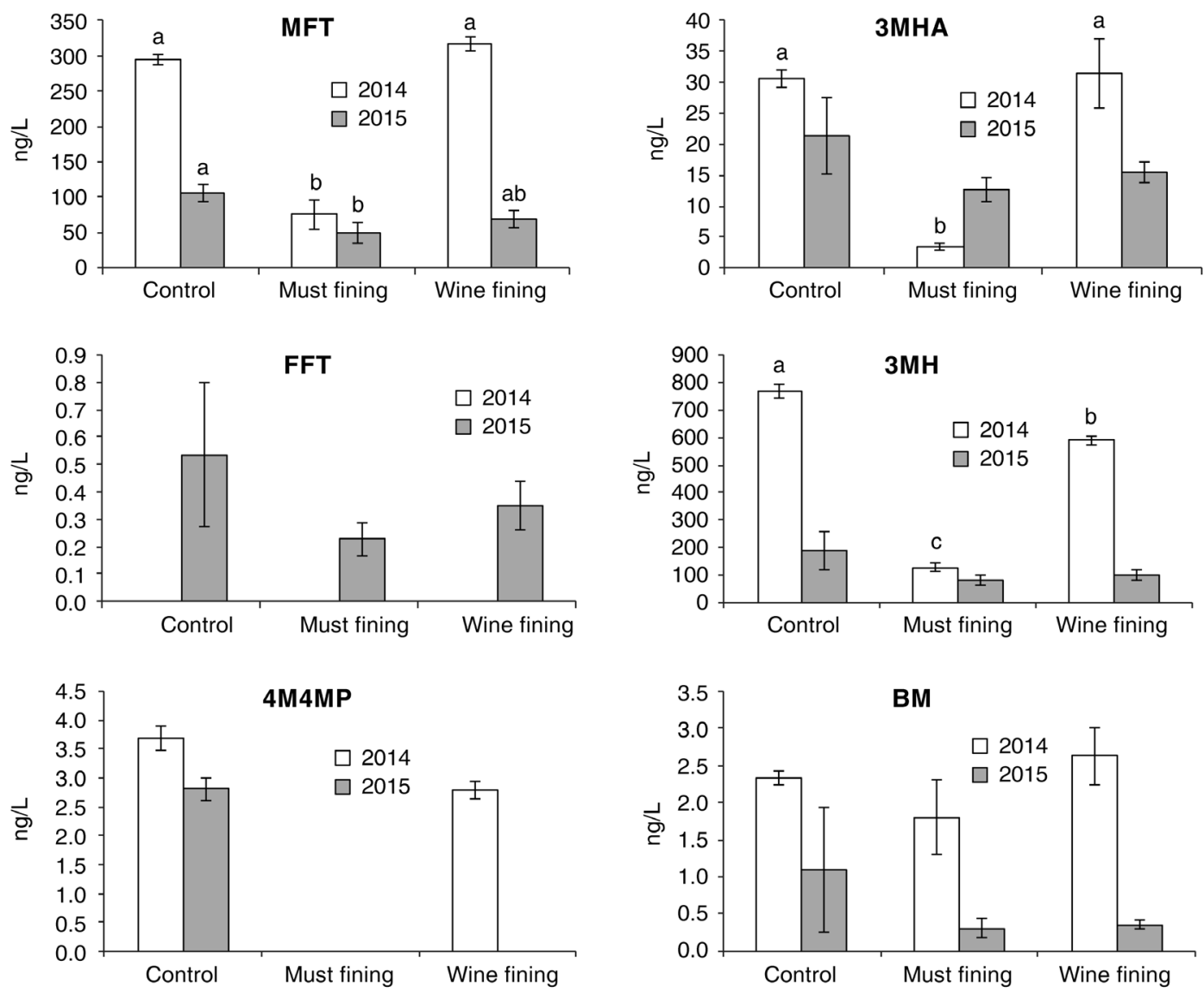

Figure 1 Contents of 3-mercaptohexan-1-ol (3MH), 3-mercaptohexyl acetate (3MHA), 4-mercapto-4-methylpentan-2-one (4M4M2P), 2-furfurylthiol (FFT), benzyl mercaptan (BM), and 2-methyl-3-furanthiol (MFT) (expressed as ng/L of FFT) for wine control, treated with bentonite during fermentation (Must fining) and after fermentation (Wine fining) from vintages 2014 and 2015. Values are averages of independent vinifications $(n=2)$, error bars are two standard deviations. a, b, c: Different letters indicate mean is significantly different among samples at $p<0.05$ by Duncan's test after a statistically significant one-way ANOVA. 
in the wines were MFT and BM. The differences in the MFT content were significant, again showing a clear decrease in the musts treated with bentonite. For BM, the differences were not significant, although the tendency was similar. Finally, FFT was the polyfunctional mercaptan found in the lowest concentrations and only in the control wines at a level very close to the detection limit of the method $(0.2 \mathrm{ng} / \mathrm{L})$.

A similar pattern was observed for most of the polyfunctional mercaptans found in this study. The addition of bentonite to musts at the beginning of alcoholic fermentation resulted in a lower content of the compounds in the finished wines. The loss of mercaptans was also found in some of the wines fined with bentonite, but usually to a lesser extent. An explanation for this different behavior can be related to a stronger interaction of bentonites with cysteinylated and glutathionylated precursors in must, as reports for glycosidic precursors. Another potential explanation could be found in a modification of the assimilation of the precursor by the yeast caused by the addition of bentonite. The present study suggests that a common practice carried out in wineries, must fining with bentonites, can have a sensory impact on Sauvignon blanc wines because it significantly decreases the content of key varietal aromas elicited by polyfunctional mercaptans; therefore, fining of the finished wines could be a better option to preserve the varietal thiols.

\section{Conclusions}

The main objective of this study was to assess the influence of bentonite fining on the volatile profile of Sauvignon blanc wines. Numerous compounds were analyzed in wines fined at different stages of the vinification process. The efficiency of bentonite fining for protein removal was found to be better in finished wines than in musts. The conventional enological parameters of the wines were minimally affected by bentonite treatment, with only minor differences in organic acid content found. Bentonite fining modified the volatile composition of the bottled wines, but the modifications depended upon the chemical family, the vintage, and the timing of the bentonite addition. Some of the results demonstrated the impact of bentonite fining on concentrations of some long-chain fatty acids and terpenols. These data showed that bentonite treatment in must potentially causes damage to the organoleptic quality of wines because of its impact on the concentration of varietal thiols, and these results should be considered when bentonite fining is conducted in musts rich in varietal thiols.

\section{Literature Cited}

Armada L and Falqué E. 2007. Repercussion of the clarification treatment agents before the alcoholic fermentation on volatile composition of white wines. Eur Food Res Technol 225:553-558.

Ayestaran BM, Ancin MC, Garcia AM, Gonzalez A and Garrido JJ. 1995. Influence of prefermentation clarification on nitrogenous contents of musts and wines. J Agric Food Chem 43:476-482.

Baiano A, Terracone C, Longobardi F, Ventrella A, Agostiano A and Del Nobile MA. 2012. Effects of different vinification technologies on physical and chemical characteristics of Sauvignon blanc wines. Food Chem 135:2694-2701.
Blade WH and Boulton R. 1988. Adsorption of protein by bentonite in a model wine solution. Am J Enol Vitic 39:193-199.

Catarino S, Madeira M, Monteiro F, Rocha F, Curvelo-Garcia AS and de Sousa RB. 2008. Effect of Bentonite Characteristics on the Elemental Composition of Wine. J Agric Food Chem 56:158-165.

Chagas R, Monteiro S and Ferreira RB. 2012. Assessment of potential effects of common fining agents used for white wine protein stabilization. Am J Enol Vitic 63:574-578.

Chatonnet P, Dubourdieu D, Boidron JN and Pons M. 1992. The origin of ethylphenols in wines. J Sci Food Agric 60:165-178.

Coetzee C and du Toit WJ. 2012. A comprehensive review on Sauvignon blanc aroma with a focus on certain positive volatile thiols. Food Res Int 45:287-298.

Escudero A, Gogorza B, Melús MA, Ortín N, Cacho J and Ferreira V. 2004. Characterization of the aroma of a wine from Maccabeo. Key role played by compounds with low odor activity values. J Agric Food Chem 52:3516-3524.

Escudero A, Campo E, Fariña L, Cacho J and Ferreira V. 2007. Analytical characterization of the aroma of five premium red wines. Insights into the role of odor families and the concept of fruitiness of wines. J Agric Food Chem 55:4501-4510.

Etievant PX. 1991. Wine. In Volatile Compounds of Food and Beverages. H Maarse (ed.), pp.483-546. Dekker, New York.

Ferreira V, López R and Cacho JF. 2000. Quantitative determination of the odorants of young red wines from different grape varieties. J Sci Food Agric 80:1659-1667.

Ferreira V, Ortín N, Escudero A, López R and Cacho J. 2002. Chemical characterization of the aroma of Grenache rosé wines: Aroma extract dilution analysis, quantitative determination, and sensory reconstitution studies. J Agric Food Chem 50:4048-4054.

Fraile P, Garrido J and Ancín C. 2000. Influence of a Saccharomyces cerevisiae selected strain in the volatile composition of rosé wines. Evolution during fermentation. J Agric Food Chem 48:1789-1798.

Guth H. 1997. Quantitation and sensory studies of character impact odorants of different white wine varieties. J Agric Food Chem 45:3027-3032.

Lambri M, Dordoni R, Silva A and De Faveri DM. 2010. Effect of bentonite fining on odor-active compounds in two different white wine styles. Am J Enol Vitic 61:225-233.

Lambri M, Dordoni R, Silva A and De Faveri DM. 2012. Comparing the impact of bentonite addition for both must clarification and wine fining on the chemical profile of wine from Chambave Muscat grapes. Int J Food Sci Tech 47:1-12.

Lambri M, Dordoni R, Silva A and De Faveri DM. 2013. Odor-active compound adsorption onto bentonite in a model white wine solution. Chem Eng Trans 32:1741-1746.

Lira E, Salazar FN, Vincenzi S, Curioni A and López F. 2013. Effect of bentonite fining during fermentation on protein content in Macabeu wines: Comparison of pilot- and industrial-scale experiments. J Int Sci Vigne Vin 47:221-226.

Lira E, Salazar FN, Rodriguez-Bencomo JJ, Vincenzi S, Curioni A and López F. 2014. Effect of using bentonite during fermentation on protein stabilisation and sensory properties of white wine. Int $\mathrm{J}$ Food Sci Tech 49:1070-1078.

Lira E, Rodríguez-Bencomo JJ, Salazar FN, Orriols I, Fornos D and López F. 2015. Impact of bentonite additions during vinification on protein stability and volatile compounds of Albarino wines. J Agric Food Chem 63:3004-3011.

Lopez R, Aznar M, Cacho J and Ferreira V. 2002. Determination of minor and trace volatile compounds in wine by solid-phase extraction and gas chromatography with mass spectrometric detection. $\mathrm{J}$ Chromatogr A 966:167-177. 
Lubbers S, Charpentier C and Feuillat M. 1996. Etude de la rétention de composés d'arôme par les bentonites en moût, vin et milieux modèles. Vitis 35:59-62.

Mateo-Vivaracho L, Zapata J, Cacho J and Ferreira V. 2010. Analysis, occurrence, and potential sensory significance of five polyfunctional mercaptans in white wines. J Agric Food Chem 58:10184-10194.

Miller GC, Amon JM, Gibson RL and Simpson RF. 1985. Loss of wine aroma attributable to protein stabilization with bentonite or ultrafiltration. Aust Grapegr Winemaker 256:46-50.

Moine-Ledoux V and Dubourdieu D. 1999. An invertase fragment responsible for improving the protein stability of dry white wines. J Sci Food Agric 79:537-543.

Moio L, Ugliano M, Gambuti A, Genovese A and Piombino P. 2004. Influence of clarification treatment on concentrations of selected free varietal aroma compounds and glycoconjugates in Falanghina (Vitis vinifera L.) must and wine. Am J Enol Vitic 55:7-12.

Nakamura S, Crowell EA, Ough CS and Totsuka A. 1988. Quantitative analysis of $\gamma$-nonalactone in wines and its threshold determination. J Food Sci 53:1243-1244.

OIV. 2014. Compendium of International Methods of Wine and Must Analysis. Organisation Internationale de la Vigne et du Vin, Paris.

Ortega C, López R, Cacho J and Ferreira V. 2001. Fast analysis of important wine volatile compounds. Development and validation of a new method based on gas chromatographic-flame ionization detection analysis of dichloromethane microextracts. J Chromatogr A 923:205-214.

Parish KJ, Herbst-Johnstone M, Bouda F, Klaere S and Fedrizzi B. 2016. Pre-fermentation fining effects on the aroma chemistry of Marlborough Sauvignon blanc press fractions. Food Chem 208:326-335.

Pocock KF, Salazar FN and Waters EJ. 2011. The effect of bentonite fining at different stages of white winemaking on protein stability. Aust J Grape Wine Res 17:280-284.
Puig-Deu M, López-Tamames E, Buxaderas S and Torre-Boronat MC. 1999. Quality of base and sparkling wines as influenced by the type of fining agent added pre-fermentation. Food Chem 66:35-42.

Ribéreau-Gayon P. 2000. Handbook of Enology. Wiley, New York.

Sanborn M, Edwards CG and Ross CF. 2010. Impact of fining on chemical and sensory properties of Washington State Chardonnay and Gewurztraminer wines. Am J Enol Vitic 61:31-41.

Sarmento MR, Oliveira JC, Slatner M and Boulton RB. 2000. Influence of intrinsic factors on conventional wine protein stability tests. Food Control 11:423-432.

Somers TC and Ziemelis G. 1973. The use of gel column analysis in evaluation of bentonite fining procedures. Am J Enol Vitic 24:51-54.

Stankovic S, Jovic S, Zivkovic J and Pavlovic R. 2012. Influence of age on red wine colour during fining with bentonite and gelatin. Int J Food Prop 15:326-335.

Tominaga T, Darriet P and Dubourdieu D. 1996. Identification of 3-mercaptohexyl acetate in Sauvignon wine, a powerful aromatic compound exhibiting box-tree odor. Vitis 35:207-210.

van Gemert LJ and Nettenbreijer AH. 1977. Compilation of odour threshold values in air and water. National Institute for Water Supply, Voorburg, The Netherlands.

Vincenzi S, Panighel A, Gazzola D, Flamini R and Curioni A. 2015. Study of combined effect of proteins and bentonite fining on the wine aroma loss. J Agric Food Chem 63:2314-2320.

Voilley A, Lamer C, Dubois P and Feuillat M. 1990. Influence of macromolecules and treatments on the behavior of aroma compounds in a model wine. J Agric Food Chem 38:248-251.

Waters EJ, Alexander G, Muhlack R, Pocock KF, Colby C, O’Neill BK, Hoj PB and Jones P. 2005. Preventing protein haze in bottled white wine. Aust J Grape Wine Res 11:215-225. 